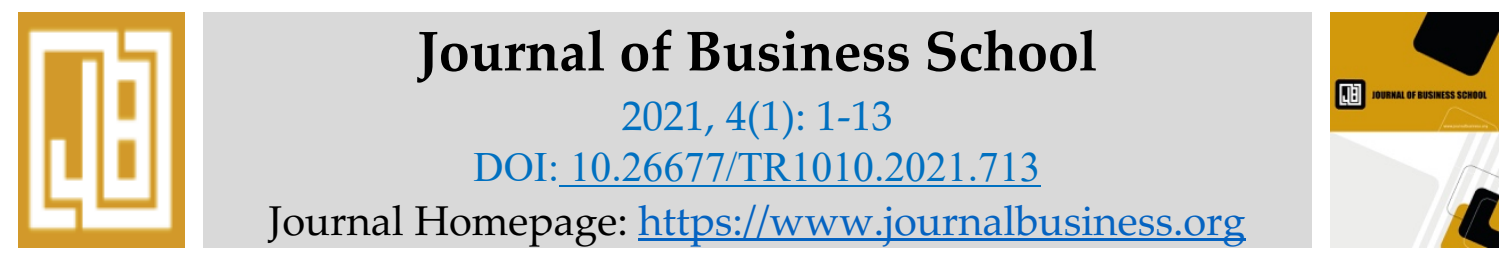

\title{
Systematic Review on Takaful and Retakaful Windows: A Regulatory Development Perspective
}

\author{
Ahmad Alrazni Alshammari \\ Affiliation: An independent Researcher \\ e-mail: a.alrazni86@gmail.com

\section{Basheer Hussein Motawe Altarturi} \\ Affiliation: PhD Candidate - IIUM Institute of Islamic Banking and \\ Finance, International Islamic University Malaysia \\ e-mail: altarturibasheer@yahoo.com

\section{Jassem Alokla} \\ Affiliation: Lecturer - Economics and finance subject group at School of \\ business and Law, Portsmouth University \\ e-mail: jassem.alokla@port.ac.uk
}

\begin{abstract}
This paper reviews the regulatory developments of takaful and retakaful windows in the international regulatory bodies and selected jurisdictions. The takaful and retakaful window operations as a business model has been adopted in some countries such as Indonesia, Nigeria, Pakistan and Turkey to achieve certain objectives, including encouraging financial inclusion, tapping a new market segment, and boosting competitiveness. On the flip side, takaful and retakaful window operations are banned by the regulators in other countries such as Brunei, Qatar and Saudi Arabia due to concerns on adherence to Shariah governance, and the performance of standalone full-fledged takaful operators, which have the capability of handling the demands of their respective markets. The paper investigates the takaful and retakaful window operations in the six jurisdictions i.e. Indonesia, Pakistan, Turkey, Nigeria, Kenya and Bangladesh. It also discusses the current regulatory development of transferring the takaful and retakaful windows business into full-fledged takaful players in Indonesia and Turkey, and the decision to maintain the windows model as the ideal model in Pakistan.
\end{abstract}

Keywords: Takaful Window; Retakaful Window; Systematic Review 


\section{INTRODUCTION}

Takaful is a form of Islamic insurance ${ }^{1}$ that is well-known and common in both the industry and academia. It plays a role in providing financial protection within the boundaries of Islamic rules and principles. The Islamic Financial Services Industry Stability Report 2020 states that globally there are about 353 takaful/retakaful institutions operating in 33 countries. The report shows that almost one third of the 353 firms are functioning as takaful (88 firms) and retakaful (28 firms) windows and not full-fledged standalone operators. On a whole, the takaful market recorded a relatively steady average growth of 8.5\% from 2011 to 2018, with takaful contributions reaching USD 27.07 billion (IFSB, 2020a).

The takaful market, both full-fledged and windows, is globally gaining acceptance and recognition in Muslim and non-Muslims countries, where many regulatory and supervisory authorities (RSAs) embrace the need to develop regulatory guidelines addressing the specificities of the takaful business. For example, the Inter-African Conference on Insurance Markets, a body represented by 14 jurisdictions located in sub-Saharan Africa, has amended the insurance code regulation to address the takaful activities (Atlas Magazine, 2019). Another example is Morocco, where takaful regulation has been passed and approved by different layers, e.g. the House of Councillors and the Parliament of Morocco (Middle East Insurance Review, 2019a). Turkey, where takaful window operations ${ }^{2}$ is well-established, has eight conventional insurance companies offering takaful windows (Middle East Insurance Review, 2019b).

Takaful windowsare an essential component in the takaful market, as it helps to penetrate new regions and increase the growth and volume of the market as a whole. However, there is a noticeable dearth in the literature relating to takaful windows ${ }^{3}$, although several researches discuss the banking windows' background (Boone \& Özcan, 2020; Shabbir, 2019; Hati \& Yasin, 2017). The main goal of this paper is to explore the contributions by the international standard-setting bodies, and the practices of selected jurisdictions in relation to takaful window operations.

The paper is structured into six sections. The first section is introductory, followed by an overview of takaful windows. Section three, on international regulatory bodies, provides discussions on takaful windows' standards and guidelines. A discussion on the practices of the leading three jurisdictions in takaful window operations, namely Indonesia, Pakistan and Turkey, is presented in section four. The fifth section presents the challenges and opportunities of takaful windows market and the final section provides concluding remarks.

\section{TAKAFUL AND RETAKAFUL WINDOWS: AN OVERVIEW}

Takaful window is a unique business model. IFSB-25 defines it as a part of a conventional insurer/reinsurer (which may be a branch, a unit or a division) that provides takaful/retakaful services, but which does not have a separate legal identity (IFSB, 2020b). The conventional player that offers Shariah-compliant products is known as a host undertaking in the industry. The host should ensure proper financial segregation of the window operations and maintain separate accounts relating to assets, liabilities, capital, profits, and losses. This is important since there is an interrelation cash-flow between the host and its windows, e.g., partnership profit share and agency fee, as stated in paragraph 129 in IFSB-20 (IFSB, 2018).

Takaful windows are not commonly practiced in all jurisdictions, and where it is practiced, divergences and varying ways can be seen in its implementation. Asafa (2020) states that some jurisdictions ban

\footnotetext{
${ }^{1}$ The industry consists of several Islamic insurance models in different countries, i.e., Saudi Arabia uses the cooperative insurance model, Sudan adopts the mutual insurance model, Iran uses the insurance model, Turkey uses the participation insurance model, and finally the takaful model adopted in many other countries such as Kuwait and Malaysia. Regardless of the technical differences, all these models are considered Shari' ${ }^{`}$ ah-compliant.

2 "takaful windows" or "takaful window operations" is used to also include the retakaful business, unless otherwise specified.

${ }^{3}$ The authors explore all takaful researches published in Scopus database using "TITLE-ABS-KEY (takaful OR (insurance AND (Islamic OR s?aria*)))" command, and there is no paper written about takaful window among the 509 document results.
} 
takaful window operations, e.g., Brunei, Malaysia, Qatar, Saudi Arabia, Sudan and the United Arab Emirates. He also presents those jurisdictions that allow it, e.g., Indonesia, Bahrain, Kenya, Mauritius, Nigeria, Pakistan, Turkey, the United Kingdom, and international financial centres such as the Labuan International Business and Financial Centre in Malaysia, the Dubai International Finance Centre in the UAE, and the Qatar Financial Centre.

Window operations are also allowed in some other jurisdictions, e.g., the Finance Law 2020 article 103 in the Algerian regulation permits conventional insurance to offer takaful activities (Atlas Magazine, 2020), and section 24 in takaful rules 2012 grants the conventional insurance players the right to establish Islamic windows. The RSAs that allow conventional insurance companies, generally known as the host, to launch a window under its umbrella have different goals to achieve through the window practices (Asafa, 2020). Among the justifications of the RSAs in supporting this business model are: 1) the window approach is considered a way of encouraging financial inclusion. Many Muslims who live in non-Muslim countries exclude themselves from the insurance system due to the prohibitions in conventional insurance. For example, SAAR Assurances, the Cameroonian insurance company that operates in different countries in Africa, established its window unit in 2020 to promote financial inclusion (Middle East Insurance Review, 2020a). 2) windows can be seen as an expansion tool for tapping a new market segment. For example, Kenya Re, a conventional reinsurance firm, saw the opportunities in takaful and started its retakaful window in 2013. It will expand to the Egyptian market as a window player (Middle East Insurance Review, 2020b). Some international players, e.g., AIG and Hannover Re, have also opened takaful and retakaful units to meet the demands of niche market in different regions. 3) windows can be a useful tool in boosting competitiveness and increasing the takaful market penetration, e.g., issuance of Takaful Rules 2012 in Pakistan (Vizcaino, 2012).

On the other hand, some RSAs do not allow conventional insurance to offer any Shariah-compliant products. In Kuwait, for example, Article 29 in law no 125 in 2019 states that conventional insurance is not allowed to offer takaful products (Abuljebain, Wakerley, \& Garrett, 2020). In general, the RSAs that are not in favour of windows have specific considerations, which include: 1) Shariah governance framework might be difficult to maintain, which could create misunderstanding and a reputational risk on the authenticity of Shariah compliance. 2) the market has sufficient takaful players, who can meet the needs of the industry.

\section{INTERNATIONAL REGULATORY BODIES}

The Islamic financial system has various international regulatory bodies carrying different mandates, with the ultimate goal of improving the Islamic financial industry. The Accounting and Auditing Organization for Islamic Financial Institutions (AAOIFI) is one of the leading international organizations for the Islamic finance industry. As of January 2021, it has issued 100 standards covering different areas of concern, i.e., Shariah, accounting, auditing, ethics and governance. A few of these standards ${ }^{4}$ discuss takaful, but there is nothing specific to takaful windows.

The second organization that plays an important role is the International Islamic Liquidity Management Corporation (IILM), which is an international organization established to create and issue Shariah-compliant financial instruments to facilitate effective cross-border Islamic liquidity management. These instruments could be used by takaful, but this discussion is out of the scope of this paper. The third international organization is the Islamic Financial Services Board (IFSB). The IFSB's work will be discussed in detail in the following section since it has significant contribution on takaful windows.

The IFSB is an international standard-setting organization which aims to promote and enhance the soundness and stability of the Islamic financial services industry by issuing prudential standards and

\footnotetext{
${ }^{4}$ FAS 12: General Presentation and Disclosure in the Financial Statements of Takaful Companies; FAS 13: Disclosure of Bases for Determining and Allocating Surplus or Deficit in Takaful Companies; FAS 15: Provisions and Reserves in Takaful Companies; FAS 19: Contributions in Takaful Companies
} 
guiding principles for different sectors, i.e., banking, capital markets and insurance sectors. As of January 2021, the IFSB has issued 34 documents, including 24 standards, three technical notes, and seven guidance notes for the three sectors. For the takaful sector, the IFSB has published six standards and one guidance note ${ }^{5}$ which complement the conventional global regulations issued by the International Association of Insurance Supervisors (IAIS).

This paper explores the IFSB's published standards and extracts the areas relevant to takaful windows (since there is no particular standard specifically on windows). It has to be noted that the earlier IFSB takaful standards - IFSB-8, IFSB-11, IFSB-14 - have not discussed the takaful windows in-depth, and have approached is as being the RSAs role to modify and adjust the regulations to be applicable and adaptable for takaful windows (IFSB, 2013; IFSB, 2010; IFSB, 2009). However, the more recent standards - IFSB-18, IFSB-20 and IFSB-25 - state several guidance elaborating on takaful windows operations (IFSB, 2020b; IFSB, 2018; IFSB, 2016). The following table extracts the key points relevant to takaful window operations.

\footnotetext{
${ }^{5}$ The six takaful/retakaful standards and one guidance note issued by the IFSB are: IFSB-8: Guiding Principles on Governance for Takâful (Islamic Insurance) Undertakings, published in 2009; IFSB-11: Standard on Solvency Requirements for Takâful (Islamic Insurance) Undertakings, published in 2010; IFSB-14: Standard on Risk Management for Takāful (Islamic Insurance) Undertakings, published in 2013; IFSB-18: Guiding Principles for Retakāful (Islamic Reinsurance), published in 2016; IFSB-20: Key Elements in the Supervisory Review Process of Takâful/Retakâful Undertakings, published in 2018; IFSB-25: Disclosures to Promote Transparency and Market Discipline for Takāful/Retakāful Undertakings, published in 2020; Guidance Note-5: The Recognition of Ratings by External Credit Assessment Institutions (ECAIs) on Takâful and ReTakâful Undertakings
} 


\begin{tabular}{l}
\hline IFSB-18 \\
RETAKAFUL \\
\hline Establishment of retakaful \\
windows \\
Paragraph 24 states the \\
required high capital for full- \\
fledged retakaful and the \\
presence of technical expertise \\
in conventional reinsurance \\
may encourage the industry \\
for retakaful windows.
\end{tabular}

\section{Potential issues}

Paragraph 25 emphasizes the attention needed by the RSAs, where a close connection between a retakaful window and its host may impair the Sharīah compliance of the operations of the window.

\section{Segregation of funds}

Paragraph 114 states that the assets of a retakaful window should be segregated from the assets of the host entity, and the liabilities of a window should be ring-fenced ${ }^{6}$.

Paragraphs 81 and 87 emphasize on the segregation of assets, where the assets of a window should be identified and should be in line with Shariah principles. These assets must not commingle with those backing the liabilities of the conventional operations.

\section{IFSB-20 \\ SUPERVISORY REVIEW PROCESS \\ IFSB-25 \\ DISCLOSURES}

Definition of takaful windows

Paragraph 129 defines the window as a specific division established within the conventional entity (referred to here as the "host"), with its own identified assets and liabilities, separate from those of the conventional insurance/reinsurance operations.

\section{Sharī'ah Governance}

Paragraph 131 emphasizes the existence of appropriate Shariah governance in window operations. From a supervisory review perspective, RSAs should confirm that window operations have in place controls designed to secure end-to-end Shariah compliance.

\section{Segregation of funds}

Paragraph 132 states several points that need to be considered by an RSA in the supervisory review process, which are:

i. whether a window has adequate policies and processes to prevent the commingling of conventional and takaful funds;

ii. whether the separation of Islamic assets and funds from nonShariah-compliant assets and funds is transparent; and iii. whether the operations of a window involve features that have the

\section{General disclosure}

Paragraph 186 advocates for windows to provide information about the conventional host, stating the organizational relationship between the window and the host, since a window may be established in different forms.

\section{Applicability}

Paragraph 185 states that many of the prudential disclosure requirements for takaful undertakings are applicable to takaful windows, or applicable with minor modifications reflecting the fact that a window is not a legal entity.

\section{Disclosure and segregation of funds}

Paragraph 187 states several disclosure requirements that should be put in place by a takaful window as:

i. arrangements for the segregation of funds from those of the host.

ii. the possible flows of funds that may take place between a takaful window and its host (e.g. profit-sharing portion and wakalah fee).

iii. any joint transactions between a window and its host - for example, joint placement of retakaful/reinsurance.

\footnotetext{
${ }^{6}$ Defin
} 


\begin{tabular}{ll}
\hline Solvency & $\begin{array}{l}\text { effect of undermining } \\
\text { effective segregation. }\end{array}$ \\
$\begin{array}{l}\text { Paragraphs } 101 \text { and } 106 \text { states } \\
\text { the importance of Shariah } \\
\text { compliance in the case of } \\
\text { seeking support for capital and } \\
\text { liquidity from the host. The } \\
\text { Qard mechanism (draw-down } \\
\text { or/and earmarked) should } \\
\text { fulfil the requirements of the } \\
\text { Shariah advisers with regard to } \\
\text { Sharìah compliance. }\end{array}$ & $\begin{array}{l}\text { Paragraph } 188 \text { relates to } \\
\text { disclosing the Qard given by } \\
\text { the host in supporting the } \\
\text { window's financial position. }\end{array}$ \\
& \\
&
\end{tabular}

\section{TAKAFUL AND RETAKAFUL WINDOWS IN SELECTED JURISDICTIONS}

As stated earlier, takaful window operations are allowed in various countries. This section explores the experiences of six jurisdictions, i.e., Indonesia, Pakistan, Turkey, Nigeria, Kenya, and Bangladesh, in adopting this model. The maturity of regulatory framework may vary among the selected countries.

\subsection{Indonesia}

Indonesia's takaful industry witnessed increase of 8.6\% growth in 2018 compared to 2017, reaching USD 1.1 billion. The takaful contributions (premiums) were generated mostly from the family business lines. However, the industry growing in line with the broader Shari'ah ecosystem set in Indonesia's Financial Services Master Plan?

The Indonesian insurance market has 13 full-fledged takaful companies and 49 conventional insurance companies that have Islamic units (or what is referred to as takaful windows in this paper). The Financial Services Authority (OJK), the RSA for the insurance industry in Indonesia, has played a great role in developing the regulation over time. In 2003, the government issued a policy that allows window operations, and within a span of only four years, the number of window operators jumped to 40 . The small amount of capital requird - USD 200,000 - may have been the main reason of this growth in the number of players (Sukmana \& Hidayat, 2014). OJK has since amended the regulations for not allowing Islamic units/windows in conventional insurance, and had requested all the 49 players to submit a spinoff plan for their Islamic insurance units in October 2020, with a four-year timeframe given for its implementation (Middle East Insurance Review, 2019c).

Insurers with Shariah-compliant windows are required by the new law to spin-off their Shariah business units into fully capitalized subsidiaries by 2024. The key to stepping up takaful operators' genuine new value propositions include product differentiation, pricing, innovation and distribution. Currently, there are 13 full-fledged or standalone takaful operators, including four recent spin-off windows.

In 2014, OJK issued Insurance Law 40 stating that two conditions need to be considered by an insurer (host) that has a Shariah unit/window under its umbrella. The host should completely separate the operations in two separate entities, technically known as a spin-off when either one of the following situations occur: i) the value of a window's funds ${ }^{8}$ have reached half of the aggregate insurance funds;

\footnotetext{
${ }^{7}$ SwissRe 2019 edition. See also Indonesia Sharī'ah Insurance Association (AASI) Report, March 2020.

${ }^{8}$ In Indonesia, it refers to Tabarru' fund and participants' investment funds. Also a takaful operator is called a Shariah insurance company.
} 
or ii) within ten years after the enactment of Insurance Law 40 (i.e. by October 2024). A further regulation issued in 2016, POJK 67, entitled "Licensing and Institution of Insurance Companies and Reinsurance Companies", states that a window could be transferred into a newly licensed takaful (firm) or an existing takaful operator. An update to this, POJK 67, OJK issued a draft regulation ${ }^{9}$ in November 2019 to provide clear directions on the spin-off requirements to assist a host in assessing the feasibility of separating the licenses and having a standalone takaful operator (Milliman, 2019).

The draft regulation discusses various areas that concern windows and their hosts, e.g., capital requirements and spin-off process. A takaful operator must have at least IDR 100 billion for paid-up capital and IDR 50 billion for equity for capital requirements. However, the draft regulation grants flexibility to spin-off windows, allowing them to fulfil only half of the capital requirement at establishment. However, the firm needs to meet the full requirement within two years from the date of spin-off approval.

Sharing services between the conventional insurer "the old host" and the new takaful operator "the spin-off window" is another advantage accorded to them for a certain period of time, i.e., maximum three years. Upon the OJK's approval, the regulation specifies the functions which can be shared and those otherwise, e.g., the new takaful operator should have its own board of directors, Shariah Supervisory Board and other mandatory bodies.

The draft regulation elaborates on the spin-off process - where a host is required to submit plans, including a timeline, on how the window's separation will be conducted. This spin-off process requires transferring a portfolio of the window, including assets, liabilities, e.g. Qard and equity to the new takaful operator.

\subsection{Pakistan}

The Pakistani takaful market witnessed an evolution in gross written contributions (GWC), increasing by $20.7 \%$ compared to previous year and recording a total of USD 252 million in 2018. The growth is supported by the consumer's acceptability, and an increase in the number of new takaful windows (IFSB Stability Report, 2020). Interestingly, the market consists of five full-fledged takaful operators and 29 takaful windows, where the windows represent $68 \%$ of GWC, i.e., USD 172.8 million.

The operations of takaful started in 2005 with the issuance of takaful rules by the Securities and Exchange Commission of Pakistan (SECP). At that time, conventional insurance was not allowed to offer any Shariah-compliant products. However, the regulations changed in 2012, where conventional insurance companies were granted the option to carry out takaful window operations, as stated in Section 24, Takaful Rules, 2012 (Middle East Insurance Review, 2019d). Vizcaino (2012) stated that SECP allowed window practices in the Takaful Rules 2012, to improve competitiveness and raise the takaful market share, especially since the conventional players had well-connected networks with larger distributional channels.

The following practices, derived from different Pakistani conventional insurers, provide an insight into the establishment ${ }^{10}$ of their window operations:

1) the host (known as an operator) has to form a Waqf fund (irrevocable fund), known in the industry as Participants' Takaful Fund (PTF). This fund should be a separate and independent entity that is able to own and possess assets in different forms, e.g., cash, movable and immovable properties, as long as its complies with Shariah rules and principles.

2) To establish the PTF, the host, as required by Circular 8 of 2014, must transfer Rs 100,000 of statutory funds into a separate bank account for the window takaful operations. The host has to cede Rs 500,000 to the PTF as a Waqf money, which is to be invested in Shariah-compliant

\footnotetext{
${ }^{9}$ It is still at consultation stage to obtain the feedback from the market players.

${ }^{10}$ The authors explored the legal status and nature of business under different operators e.g., Premier Insurance Limited, Jubilee General Insurance Company Limited
} 
instruments, and any generated investment income could be used to pay benefits to participants or defray PTF expenses.

3) The host is responsible for managing the PTF against a predefined fee known as Takaful Operator's fee, taking into account the considerations of Waqf Rules ${ }^{11}$, which governs the relationship of Operator, Waqf and Participants for management of takaful operations, investment of Waqf and Operator's Fund as approved by the Shariah Advisor of the Operator.

4) The Operator maintains the Waqf accounts so that the assets and liabilities of Waqf remain separately identifiable. The Operator's financial statements are prepared so that the financial position and results from Waqf and the Operator operations are shown separately.

\subsection{Turkey}

In December 2017, the RSA for the insurance industry in Turkey, the Ministry of Treasury and Finance ${ }^{12}$ introduced a new regulation named "Procedures and Principles of Participation Insurance Business". The regulation aimed to set out the procedures and principles with regard to participation insurance or takaful, to ensure the system's reliability and safeguard the participants' rights and interests. Participation insurance ${ }^{13}$ is one of the models that classified as Islamic insurance.

The Participation Insurance Regulation stated in Article 4 that an insurer's management may perform the activities by following one of the defined models below:

i. Proxy model: The insurance company's management receives a proxy fee in return for the management of the risk fund management and other technical and legal operations related to the insurance.

ii. Partnership model: The insurance company's management receives a proxy fee in return for the management of the risk fund management and other technical and legal operations related to the insurance. The fee is determined by profit distribution principles within the framework of the effort-capital partnership,

iii. Hybrid model: The insurance company's management receives a proxy fee in return for the management of the risk fund management and other technical and legal operations related to the insurance. All profit is distributed to the participants. However, the investment profit is shared between the participant and the insurance company based on a pre-determined ratio.

iv. Flexible model: The management's fees and ratios shall be determined between the insurance company and the participant before executing the insurance agreement. An Advisory Committee should approve this model.

In terms of separation of funds, Article 6 emphasizes that an insurance company shall manage the risk funds created by the participants and the funds of the shareholders/members separately.

The Turkey Insurance Association (TSB) reported the Turkish insurance industry witnessed a growth of $13.3 \%$ in 2019 , recording TRY 69.2 billion in premiums. In the same year, the participation insurance market outstandingly grew by $54 \%$, compared to 2018, contributing around $5 \%$ or TRY 3.4 billion to the industry's premiums. The growth was recorded by four Islamic insurance and eight windows operators (COMCEC, 2019). However, the allowing of window operations expired in December 2020, and

\footnotetext{
11 This represents both the Waqf Deed and PTF Policies

${ }^{12}$ Şenocak, Kösoğlu, \& Karakaşlar (2020) state that there are five Turkish regulatory bodies supervising the insurance and reinsurance sector - the Insurance and Private Pension Regulation and Supervision Agency (IRSA); Union of Chambers and Commodity Exchanges of Turkey; Financial Crimes Investigation Board; Ministry of Treasury and Finance; and Ministry of Trade.

${ }^{13}$ Participation insurance is defined in the regulation as a type of insurance which is based on joint risk participation and cooperation where the participants contribute to the risk fund ("Risk Fund"), which is established to ensure the fulfilment of the compensation and/or saving payment requests of the participants and which is managed by an insurance company, in accordance with participation finance principles.
} 
extended for two years. This is in line with Article 252 of the $11^{\text {th }}$ Development Plan ${ }^{14}$ 2019-2023 to support and strengthen the overall Islamic finance system.

\subsection{Nigeria}

The National Insurance Commission (NAICOM) is the responsible regulatory and supervisory authority for insurance business in Nigeria. It has granted a licence to 58 insurance companies, including four full-fledged operators and two windows that operate based on Islamic principles. Initially, the takaful business was not guided by any regulatory initiative, where the African Alliance Insurance company introduced takaful services in 2004, alongside its core conventional insurance services (Middle East Insurance Review, 2020c). However, NAICOM recognised the development of the takaful business and issued Guidelines for Takaful-Insurance in 2013, with an aim to enhance financial inclusion, which subsequently reflected in the increase of insurance penetration and increase the contribution of insurance to the national GDP of the country.

The guidance materials provided in the Guidelines are applicable to window operators as stated in Paragraph 1.8. For example, the host of window operations should ensure the funds are segregated between the conventional and Islamic funds. Also, the host should establish investment policies for the window's funds, bearing in mind the 'ring-fenced' concept, to avoid leakage and comingling with noncompliant funds at any point in the life cycle. This particular business generally confronts key challenges in finding diversified investable assets (Lotus Capital, 2020).

\subsection{Kenya}

The Insurance Regulatory Authority (IRA) is a statutory government agency established to regulate, supervise and develop the Kenyan insurance industry. IRA prepared the Strategic Plan 2013-201815 to enhance the industry and make it effective to the economy, the Strategic Plan states that takaful is considered an emerging trend which shows a good opportunity to increase insurance penetration through promoting the inclusive and competitive insurance industry.

The IRA issued Takaful Operational Guidelines and Operations of Takaful Regulations in 2015 and in 2018 respectively, that enable conventional insurers to offer Islamic products. For window operations, the Guidelines and the Regulations state the host should consider the followings:

- Establish a separate wing/division to handle takaful business.

- Appoint a head for the takaful operations who has the relevant experience and knowledge.

- Report separately assets, liabilities, revenues and expenses of the window from the parent firm.

- Ensure separation of the takaful and conventional business.

- Ensure that the words "Takaful Window" are displayed in all documents pertaining to takaful operations.

According to the insurance industry annual report in 2019, the industry has 61 licensed insurers, including five reinsurers. Takaful Insurance Of Africa is the only full-fledged operator while Kenya Re is the first local company to launch a Retakaful window. Kenya Re started the operation in 2013, with an objective to penetrate new markets and develop new products that meet the rapid growth of Islamic finance in the region.

\footnotetext{
${ }^{14}$ The Eleventh Development Plan (2019-2023) was approved in the 105th plenary session of The Grand National Assembly of Turkey on 18 July 2019, in accordance with the provision of the Law No. 3067 dated 30 October 1984

${ }^{15}$ This Strategic Plan had been revised in June 2016.
} 


\subsection{Bangladesh}

The Bangladeshi insurance industry is governed by the Insurance Development and Regulatory Authority (IDRA) since 2010. It follows the regulatory reforms by the Government of Bangladesh that enacted the Insurance Act 2010, repealing the Insurance Act 1938, to develop and regulate the insurance business. Article 7 in the Insurance Act 2010 grants permission only to conventional life insurance companies, not general insurers, to set up takaful windows.

The industry consists 78 insurers, including 11 firms that operate based on Islamic rules and principles. Islami Insurance Bangladesh Ltd. is the first Islamic insurance company that started operation in 1990 (Khan et al., 2016). The industry has 12 conventional insurers that offer Islamic products (GolzareNabi and Rahman, 2019). Takaful operators and windows face a challenge in meeting the regulatory requirements to invest $30 \%$ of their investable funds with government securities.

\section{CHALLENGES AND OPPORTUNITIES OF THE TAKAFUL AND RETAKAFUL WINDOW MARKETS}

Takaful window operations is a unique business approach, with its own challenges and opportunities. Researchers Dikko (2019), Laçïnbala \& Ünsal (2019), Magomadova eta. (2017), Hidayat (2014), and Odierno (2006) have written several key points related to this matter.

\subsection{Challenges}

Among the challenges in the implementation of takaful windows include: 1) lack of understanding on the related Shariah-compliance functions, resulting in possible failure in implementing a proper Shariah governance framework (since the window business may be operating based on the conventional mindset); 2) a limited range of investible assets or/and impose investment in governmanl securities; 3) Family takaful window products include both investment and protection elements. The takaful window may be involved in investments that include prohibited components, e.g., riba, gharar and maysir; 4) Difficulty in branding and marketing, where offering both takaful and conventional insurance products under the same umbrella may result in lack of clarity among potential customers on the differences between the products; 5) Insufficient knowledge and understanding in takaful among staff, which gives rise to the possibility of mis-selling and misleading the clients and potential clients. This lack of knowledge may also result in failure to explain the differences between takaful and conventional insurance products being offered; and 6) There is a high possibility that the risks borne by the host, including windows risk, would be ceded to its conventional reinsurance arm.

\subsection{Opportunities}

On the other hand, there are various interrelated opportunities of establishing takaful windows. These can include: 1) windows can meet the clients' needs, e.g., minority Muslims in non-Muslims countries or in countries with fewer demand for takaful products, where its establishment under a host would make the business economically feasible since many functions are handled and managed by the host. This business model may boost takaful demand as it allows the showcasing of takaful's features and characteristics, thus may be able to convince non-Muslim consumers on the value of takaful; 2) In markets unfamiliar with takaful, window operations could be the first stage in developing the necessary regulation to support the sector as it requires less time and resources compared to having full-fledged takaful operations; 3) The windows model allows the host to offer competitive prices in a low-scale demand due to shared resources and spreading of management expenses; 4) A takaful window can benefit from the host's well-established brand and its distribution channels; 5) The windows business model should be a temporary solution to test the market at the initial stage, as its establishment does not require a large investment. 


\section{CONCLUSION}

The RSA generally determines specific objectives to develop and strengthen its respective insurance industry, which may cover both conventional insurance and takaful. Each RSA may have a different plan as no one framework fits all in guiding the stability of the industry and protecting the policyholders/participants' interests. Some RSAs may permit windows operations for financial inclusion purposes, to encourage foreign investments in a new region or increase the takaful market's penetration by boosting competition. Nevertheless, some RSAs are concerned with ensuring a proper Shariah governance framework since a window is generally managed by a host, which may create issues of trust with regard to the verification of Shariah-compliant transactions.

Indonesia currently has the largest number of window operators. OJK recently updated POJK 67 (issued in 2016), with a new draft regulation in November 2019 to prepare and guide their windows operators for spin-off from their hosts, with a view that proper regulation may boost the confidence and reduce uncertainties in the market. Similarly in Turkey, the market is moving towards full-fledged takaful operations, and it is currently one of the components that the government is working on in its plan to develop the country's Islamic financial system. However, Pakistan, Nigeria, Kenya and Bangladesh are still permitting windows operations. With their positive growth increasing from year to year. The regulators of those jurisdictions have not given any indication of preparing windows to spin-off from their hosts.

It can be concluded that implementing takaful windows bring about both challenges and opportunities for a jurisdiction, and since each jurisdiction has different and unique market environments, RSAs need to study all the aspects in their respective markets. This paper is limited to a study within the major jurisdictions with takaful window operations. However other countries may also have interesting regulatory developments.

\section{References}

Abuljebain, R. D., Wakerley, S., \& Garrett, L. (2020). Insurance and Reinsurance in Kuwait: Overview. Retrieved from Practical Law: UK Home: https://uk.practicallaw.thomsonreuters.com/8-6295351?transitionType $=$ Default\&contextData $=($ sc.Default $) \&$ firstPage $=$ true

Asafa, D. A. (2020). WP-16: Regulatory and Supervisory Issues in Takaful Windows. Kuala Lumpur: Islamic Financial Services Board.

Atlas Magazine. (2019). CIMA: Regulation of Takaful Insurance. Retrieved from Atlas Magazine: Insurance and Reinsurance News: https://www.atlas-mag.net/en/article/cima-regulation-oftakaful-insurance

Atlas Magazine. (2020). Takaful Insurance in Algeria. Retrieved from Atlas Magazine: Insurance and Reinsurance News: https://www.atlas-mag.net/en/article/takaful-insurance-in-algeria

Boone, C., \& Özcan, S. (2020). Oppositional Logics and the Antecedents of Hybridization: A CountryLevel Study of the Diffusion of Islamic Banking Windows, 1975-2017. Organization Science, 122.

Dikko, M. (2019). An Examination Of Shariah Compliance In Takaful Window Operations. International Journal of Economics, Commerce and Management, Vol. VII, Issue 1, January 2019.

GolzareNabi, M., \& Rahman, M. M. (2019). Exploring Potentials and Challenges of Takaful in Bangladesh. The Quarterly Journal of Islamic Economics Research Bureau, Vol. 29, No 01 \& 02, January-June 2019

Hati, S. R., \& Yasin, U. N. (2017). Muslim Consumers' Knowledge and Preference for the Islamic Banking Window or the Full-Fledged Islamic Bank. 30th International Business Information Management Association Conference-Vision 2020: Sustainable Economic Development, Innovation Management, and Global Growth (pp. 4915-4921). International Business Information Management Association. 
Hidayat, S. E. (October, 2014). Takaful Window: Advantages and Disadvantages. IFN Report, Volume 11. Issue 40.

IFSB. (2009). IFSB-8: Guiding Principles on Governance for Takāful (Islamic Insurance) Undertakings. Kuala Lumpur: Islamic Financial Services Board.

IFSB. (2010). IFSB-11: Standard on Solvency Requirements for Takäful (Islamic Insurance) Undertakings. Kuala Lumpur: Islamic Financial Services Board.

IFSB. (2013). IFSB-14: Standard on Risk Management for Takāful (Islamic Insurance) Undertakings. Kuala Lumpur: Islamic Financial Services Board.

IFSB. (2016). IFSB-18: Guiding Principles for Retakäful (Islamic Reinsurance). Kuala Lumpur: Islamic Financial Services Board.

IFSB. (2018). IFSB-20: Key Elements in the Supervisory Review Process of Takäful / Retakäful Undertakings. Kuala Lumpur: Islamic Financial Services Board.

IFSB. (2020a). Islamic Financial Services Industry Stability Report. Kuala Lumpur: Islamic Financial Services Board.

IFSB. (2020b). IFSB-25: Disclosures to Promote Transparency and Market Discipline for Takäful/Retakāful Undertakings. Kuala Lumpur: Islamic Financial Services Board.

Khan, I., Rahman, N. N. B. A., Yusoff, M. Y. Z. B. M., \& Nor, M. R. B. M. (2016). History, problems, and prospects of Islamic insurance (Takaful) in Bangladesh. SpringerPlus, 5(1), 1-7.

Laçïbala, Y., \& Ünsal, H. (2019). An Overview on Window Model in Participation Insurance (Takaful) System. Sosyoekonomi Journal, , Vol. 27(42), 181-202.

Lotus Capital. (2020). Breaking in - Nigeria's Takaful Story. Retrieved from Lotus Capital: https://www.lotuscapitallimited.com/breaking-in-nigerias-takaful-story/

Magomadova, M., Khominich, I., Savvina, O., \& Dzhurbina, E. (2017). Formation of institutional basics of takaful in Russia. International Journal of Economic Research.

Middle East Insurance Review. (2019a). Morocco:1st Takaful Licences Set to be Issued Soon as Bill Clears Second Lawmaking House. Retrieved from Middle East Insurance Review: https://www.meinsurancereview.com/News/View-NewsLetter-

Article/id/47474/Type/MiddleEast/Morocco-1st-takaful-licences-set-to-be-issued-soon-as-Billclears-second-lawmaking-house

Middle East Insurance Review. (2019b). Takaful:Turkey's Share of Global Islamic Insurance Market Expands. Retrieved from Middle East Insurance Review: https://www.meinsurancereview.com/News/View-NewsLetter-

Article/id/49187/Type/MiddleEast/Takaful-Turkey-s-share-of-global-Islamic-insurancemarket-expands

Middle East Insurance Review. (2019c). Indonesia: 39 Insurers Yet to Announce Plans for Spinning off Takaful Windows. Retrieved from Middle East Insurance Review: https://www.meinsurancereview.com/News/View-NewsLetter-

Article/id/46839/Type/MiddleEast/Indonesia-39-insurers-yet-to-announce-plans-for-spinningoff-takaful-windows

Middle East Insurance Review. (2019d). Pakistan: Financial Regulator's Board Approves Takaful Regulations. Retrieved from Middle East Insurance Review: https://www.meinsurancereview.com/News/View-NewsLetter-

Article/id/49198/Type/MiddleEast/Pakistan-Financial-regulator-s-board-approves-takafulregulations

Middle East Insurance Review. (2020a). Guinea: SAAR Assurances Starts Takaful Window. Retrieved from Middle East Insurance Review: https://www.meinsurancereview.com/News/ViewNewsLetter-Article/id/72714/Type/Africa/Guinea-SAAR-Assurances-starts-takaful-window

Middle East Insurance Review. (2020b). Kenya: State Owned Reinsurer Eyes Setting Up Retakaful Subsidiary in Egypt. Retrieved from Middle East Insurance Review: https://www.meinsurancereview.com/News/View-NewsLetter- 
Article/id/60677/Type/Africa/Kenya-State-owned-reinsurer-eyes-setting-up-retakafulsubsidiary-in-Egypt

Middle East Insurance Review. (2020c). Nigeria:Call for review of takaful guidelinest. Retrieved from Middle East Insurance Review: https://www.meinsurancereview.com/News/ViewNewsLetter-Article?id=73599\&Type=Africa

Milliman. (2019). Indonesia: Companies to Assess the Impact of Spining Off their Syariah Business Units. Kuala Lumpur: Milliman.

Odierno, H. S. (December, 2006). Takaful Windows: An Initial Stepping Stone to Bigger Islamic Insurance Market. Middle East Insurance Review, pp. 65-66.

Şenocak, A., Kösoğlu, M., \& Karakaşlar, M. (2020). Insurance and Reinsurance in Turkey: Overview. Retrieved from Practical Law: UK Home: https://uk.practicallaw.thomsonreuters.com/5-5219388?transitionType=Default\&contextData=(sc.Default)

Shabbir, M. S. (2019). Nexus between Customer Preference and Operation of Conventional Banks Islamic wWndows in Pakistan. Journal of Islamic Marketing, Vol. 11 No. 1, 50-65.

Sukmana, R., \& Hidayat, S. (2014). Challenges and Opportunities in Developing Microtakaful in Muslim Majority Country: A Case Study of Indonesia. The 11th Harvard University Forum on Islamic Finance. USA.

Vizcaino, B. (2012). Pakistan Takaful Rules to Attract New Players. Retrieved from Reuters India: https://in.reuters.com/article/islamic-finance-pakistan-idINL6E8J51BP20120807 